\title{
Performance and microbiota of the digestive tract of Nellore calves supplemented with fungi isolated from bovine rumen
}

\author{
Thiago Alves Xavier dos Santos ${ }^{1}$ (i), Luís Miguel Gonçalves Fernandes ${ }^{1}$ (i), Pedro Paulo Xavier Carvalho1(iD, \\ Valdo Soares Martins Júnior ${ }^{1}$ (i), Suze Adriane Fonseca1 (iD), Amalia Saturnino Chaves $^{2}$ (i) and Eduardo Robson Duarte ${ }^{1}$ \\ 1. Institute of Agricultural Science, Universidade Federal de Minas Gerais, Campus Montes Claros - MG, 39404-547, \\ Brazil; 2. Department of Veterinary Medicine, Universidade Federal de Juiz de Fora, Juiz de Fora - MG, 36036-900, Brazil. \\ Corresponding author: Thiago Alves Xavier dos Santos, e-mail: thiagoax.17@gmail.com \\ Co-authors: LMGF: miguelgfff@hotmail.com, PPXC: pedro_4518@yahoo.com, VSMJ: valdo-soares1@hotmail.com, \\ SAF: suzeafonseca@gmail.com, ASC: amaliaschaves@yahoo.com.br, ERD: duartevet@hotmail.com \\ Received: 04-06-2021, Accepted: 07-09-2021, Published online: 21-10-2021
}

doi: www.doi.org/10.14202/vetworld.2021.2686-2693 How to cite this article: dos Santos TAX, Fernandes LMG, Carvalho PPX, Júnior VSM, Fonseca SA, Chaves AS, Duarte ER (2021) Performance and microbiota of the digestive tract of Nellore calves supplemented with fungi isolated from bovine rumen, Veterinary World, 14(10): 2686-2693.

\begin{abstract}
Background and Aim: In tropical semiarid regions, supplementation with fungi could contribute to rumen modulation, promoting greater production of fibrolytic enzymes and degradation of forage. The objective of this study was to analyze the effect of supplementation with fungi, isolated from the bovine rumen, on the performance and microbiota of the digestive tract of Nellore calves.

Materials and Methods: The experiment was conducted in randomized blocks evaluating eight Nellore calves that were daily supplemented with isolates of Aspergillus terreus and Trichoderma longibrachiatum, along with eight calves that were not supplemented. After 55 days, the animals were weighed, and samples of rumen fluid and feces were collected for analysis. The characteristics that showed normal distribution were subjected to analysis of variance and compared using Tukey's test. Whereas, the variables that did not show normal distribution were subjected to the Kruskal-Wallis test, and the frequencies of the bacterial and fungal genera were compared using the Chi-square test.

Results: Supplementation with fungi promoted the reduction in ruminal $\mathrm{pH}(\mathrm{p}<0.05)$. However, the final live weight; average daily weight gain; total weight gain; rumen protozoa; and the count of Enterobacteriaceae, mycelial fungi, and yeasts of ruminal fluid and feces were not influenced by supplementation $(\mathrm{p}>0.05)$. Moreover, the protozoa Eodinium spp. was identified only in supplemented calves $(\mathrm{p}<0.05)$.

Conclusion: Supplementation with the fungi presented the potential for use as possible additives because it did not alter the physiological parameters of the facultative anaerobic microbiota composition in the rumen and feces. In addition, it favored the presence of the ciliate genus Eodinium. However, further studies should be performed to better define suitable dosages for supplementation.
\end{abstract}

Keywords: Enterobacteriaceae, ruminal microbiota, rumen protozoa, semiarid region, weaning.

\section{Introduction}

Cattle directly depend on their gastrointestinal microbiota for energy metabolism, the digestion of nutrients, and the reduction of pathogenic microorganisms [1]. In particular, the stress levels and health risks of calves are high after weaning because they are still very susceptible to diseases and digestive changes during this period $[2,3]$. To reduce risks and improve food efficiency, the prophylactic administration of antimicrobials has been promoted [4]. In this context, anaerobic fungi from the rumen may play an important role as a microbial additive in ruminant supplementation due to its ability to degrade forages by producing enzymes with fibrolytic activity, which are capable of

Copyright: dos Santos, et al. Open Access. This article is distributed under the terms of the Creative Commons Attribution 4.0 International License (http://creativecommons.org/licenses/ by/4.0/), which permits unrestricted use, distribution, and reproduction in any medium, provided you give appropriate credit to the original author(s) and the source, provide a link to the Creative Commons license, and indicate if changes were made. The Creative Commons Public Domain Dedication waiver (http:// creativecommons.org/publicdomain/zero/1.0/) applies to the data made available in this article, unless otherwise stated. increasing the availability of soluble carbohydrates and amino acids [5]. This action favors the growth of rumen microbiota, thereby providing improvements in the ecosystem, in ruminal parameters, and in the productivity of the animals [6,7]. However, these fungi show laborious growth in laboratory conditions, which makes their use on an industrial scale difficult.

The anaerobic facultative fungi may be present in the rumen environment in proportions of approximately $1 \times 10^{4} \quad$ Colony-Forming Units $(\mathrm{CFU}) / \mathrm{mL}$, in animals raised on tropical pastures in the dry season $[8,9]$. These fungal isolates have been found to produce cellulases, which are enzymes important for the solubilization of fibers in tropical forages $[10,11]$ superiorly. In a previous study, beef cattle fed on lignified tropical forage presented the genus Aspergillus and Trichoderma in ruminal fluid [9], which are fungi that have shown potential for animal supplementation and for biotechnological purposes [12,13]. Selected isolates of Aspergillus spp. from the rumen environment have been found to present high levels of enzyme production that 
solubilize the lignified cell walls of plants and they do not produce mycotoxins $[9,14]$.

Therefore, in semiarid tropical regions, supplementation with fungi from the rumen could be an important alternative, contributing to improvements in the cellulolytic microbiota of the rumen and reducing the populations of pathogenic microorganisms. The objective of this study was to analyze the effects of supplementation with selected fungi isolated from the rumen, on the performance and microbiota of the digestive tract of Nellore calves.

\section{Materials and Methods}

\section{Ethical approval}

All procedures adopted by this study were approved by the Ethics Committee on the Use of Animals of the Federal University of Minas Gerais (UFMG), under number 209/2018.

\section{Study period and location}

The study was carried out from September to November 2018. The study was conducted in Montes Claros city, located north of the state of Minas Gerais, Brazil (16 $42^{\prime} 16^{\prime \prime}$ latitude south, 434' $13^{\prime \prime}$ longitude west, and $646 \mathrm{~m}$ in altitude). The region's climate is of the AW type, according to the Köppen classification, which is characterized by a rainy season in the summer and a dry season in the winter, with typical savanna vegetation. The average annual temperature is $24.2^{\circ} \mathrm{C}$ and the average annual rainfall is approximately $1050 \mathrm{~mm}$, with the drought period being from April to October [15].

\section{Study design}

The experiment was performed in a randomized block design containing 16 Nellore calves, approximately 8 months old. These comprised eight unregistered males and eight females with initial body weight (IBW) of $284.5 \mathrm{~kg} \pm 38 \mathrm{~kg}$. The diet was formulated according to the National Research Council (NRC) [16], for an average daily gain of $400 \mathrm{~g}$, and consisted of $56.79 \%$ Urochloa brizantha hay and $43.21 \%$ concentrate (Table- 1 ). This feed mixture was provided daily at 8:00 am and 3:00 pm. The quantities of food offered were adjusted daily according to the amount of leftovers, which were kept at $5 \%$ to allow consumption at will and water was provided ad libitum.

Samples of the diets were analyzed for dry matter content at $105^{\circ} \mathrm{C}$. Mineral matter, ether extract, and crude protein were analyzed according to the Association of Official Analytical Chemists [17]; whereas, neutral detergent fiber and acid detergent fiber were analyzed according to the methodology suggested by Van Soest et al. [18].

\section{Evaluation of selected fungi}

The isolated fungi were from the rumen of Nellore steers raised in an extensive system on a $U$. decumbens pasture, with mineral supplementation containing urea [9]. These fungi were identified by the sequencing
Table-1: Nutritional composition of the experimental diet.

\begin{tabular}{|c|c|}
\hline Ingredients & Experimental die \\
\hline Urochloa brizantha hay & 56.79 \\
\hline Groundcorn & 28.73 \\
\hline Soy bean meal & 2.23 \\
\hline Mineral core ${ }^{1}$ & 12.25 \\
\hline \multicolumn{2}{|l|}{ Composition } \\
\hline Dry matter & 93.00 \\
\hline Crude protein & 10.96 \\
\hline Ethereal extract & 1.17 \\
\hline Neutral detergent fiber & 74.23 \\
\hline Acid detergent fiber & 44.21 \\
\hline Mineral content & 1.17 \\
\hline \multicolumn{2}{|c|}{ 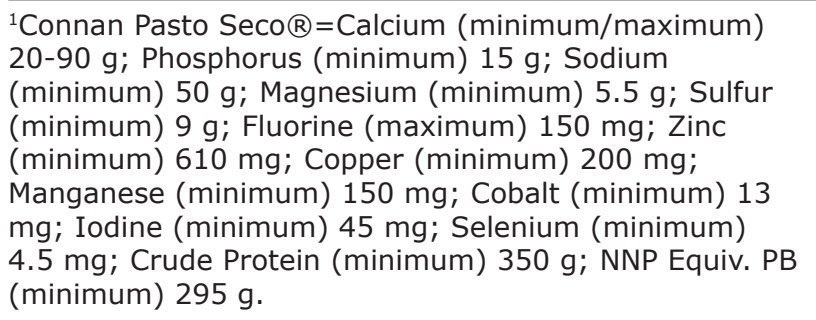 } \\
\hline
\end{tabular}

of the ribosomal DNA (rDNA), which was obtained from the amplification of the ITS region of the rDNA using the ITS1 (TCCGTAGGTGAACCTGCGG) and ITS4 (TCCTCCGCTTATTGATATGC) primers [19]. The products were analyzed in DYEnamic (Amersham Biosciences, USA) using the automated sequencing system MegaBYTE 1000 (Genome Analysis Center and Gene Expression). The obtained sequences were analyzed using BLASTn v. 2.215 of BLAST 2.0 [19]. These species were considered to be isolates with similarities of $99 \%$ or more, and the sequences were deposited in the GenBank as Aspergillus terreus (KF781532) and Trichoderma longibrachiatum (KF781535).

These isolates were selected because they are present in greater proportions in the digestive tract of cattle, do not produce mycotoxins, have no reports of causing mycoses, and show higher production levels of fibrolytic enzymes when compared to other enzymes in the digestive tract $[10,11]$.

\section{Experimental groups}

One group with eight calves (SC) supplemented with a mixture of the fungi, $A$. terreus (isolated VN15) and T. longibrachiatum (isolated VN20), was compared to the group of control calves (CC). This control group was also composed of eight calves that received only the culture medium for these microorganisms. Each group comprised four male and four female calves for block study.

The experiment lasted 70 days, with 15 days of adaptation to the diet and pens, as well as vaccination against coccidiosis and the use of anthelmintics (Albendazole $15 \mathrm{mg} / \mathrm{kg}$, subcutaneous). The other 55 days were for supplying supplementation with fungi and the experimental diet. The animals were confined in individual pens that were covered in the trough area, with dimensions of $1.5 \mathrm{~m}$ (width) $\times 3.0 \mathrm{~m}$ (length), and were parallel to each other. 
The fungus culture medium was composed of $2.5 \mathrm{~g}$ soybean, $2.5 \mathrm{~g}$ starch, $2.5 \mathrm{~g}$ dextrose, and $2 \% \mathrm{U}$. decumbens hay for $1 \mathrm{~L}$ of distilled water, as described by Freitas [20]. Before the first feeding, the SC were daily supplemented with $160 \mathrm{~mL}$ of culture medium containing $4.4 \times 10^{8} \mathrm{CFU} / \mathrm{mL}$ of $A$. terreus and $2.0 \times 10^{8} \mathrm{CFU} / \mathrm{mL}$ of $T$. longibrachiatum, mixed with $200 \mathrm{~g}$ of concentrate. The $\mathrm{CC}$ received the same amount of the culture medium without the fungi in the concentrate.

\section{Sample collection}

The animals were weighed every 15 days of the experimental period with a mechanical balance (FIZIOLA $^{\circledR}$, model 3106000 , São Paulo, Brazil). The initial and final weighing was done after fasting solids for approximately $16 \mathrm{~h}$ before feeding to minimize the differences in filling between the animals.

After 55 days of experimentation, ruminal fluid and feces were collected at 7:00 am-11:00 am, and the calves were immobilized in a containment. The ruminal fluid was collected at the ventral part of the left abdomen, cranially below the knee joint, with approximately $5 \mathrm{~cm}^{2}$, after performing the trichotomy and asepsis with a solution of polyvinylpyrrolidone-iodine (PVP-iodine 1\%). Approximately $15 \mathrm{~mL}$ of fluid was collected with sterile catheters and syringes. Before the collection of feces, asepsis of the perianal region was performed with the same PVP-iodine 1\% antiseptic, and samples of approximately $100 \mathrm{~g}$ of feces were collected directly from the rectal ampoule using gloves and sterile plastic bags. All samples were stored for up to $1 \mathrm{~h}$ and transported in isothermal boxes containing recyclable ice [9].

\section{Physical-chemical characterization of ruminal fluid}

In $5 \mathrm{~mL}$ subsamples of ruminal fluid, color, odor, and viscosity were evaluated. The microbial activity was estimated by the $0.03 \%$ methylene blue reduction test (PRAM) and the hydrogen potential $(\mathrm{pH})$ was determined with a digital potentiometer $\left(\right.$ GEHAKA ${ }^{\circledR}$, São Paulo, Brazil) [21].

\section{Analysis of aerobic and anaerobic microorganisms}

For the microbial culture, feces and ruminal fluid were handled in a laminar flow hood to facilitate decimal dilutions in tubes containing sterile saline. Subsequently, aliquots of decimal dilutions were inoculated into sterile Petri dishes containing MacConkey agar medium (KASVI ${ }^{\circledR}$, Terámo, Italy) and dilutions of $10^{3}, 10^{5}$, and $10^{7}$ in plates containing Sabouraud agar (ACUMEDIA ${ }^{\circledR}$, Michigan, United States). The plates were incubated at $37^{\circ} \mathrm{C}$ in a BOD stove and monitored for growth of Enterobacteriaceae for $48 \mathrm{~h}$ and up to 7 days for fungi [22]. The CFU/mL or CFU/g was quantified with the help of a colony counter.

The identification of the most frequent Enterobacteriaceae genera occurred after re-isolation and growth on plates containing MacConkey agar in an oven at $37^{\circ} \mathrm{C}$ for $24 \mathrm{~h}$. After exponential growth, each isolate was inoculated into tubes containing Rugai and Araújo medium, modified by Pessoa and Silva
(MBiolog Diagnósticos, Brazil). This classification considered the production capacity of indole, sulfides, and gases, in addition to the use of tryptophan, lysine, glucose, sucrose, urea, and motility $[22,23]$.

For the identification of the genera of mycelial fungi, microcultures of 23 isolates from the ruminal fluid and feces of the calves were analyzed. The micromorphological characteristics were observed using an optical microscope in the 10 and $40 \times$ objectives, considering the characteristics described by Lacaz et al. [24], and Germain and Summerbel [25].

For rumen protozoan analyses, $100 \mu \mathrm{L}$ samples of ruminal fluids were diluted in $900 \mu \mathrm{L}$ of $10 \%$ formaldehyde solution to conserve the morphological structures of these eukaryotes [26]. For quantification, decimal dilutions were made in sterile saline, classifying small $(40 \times 60 \mu \mathrm{m})$, medium $(100 \times 150 \mu \mathrm{m})$, and large $(100 \times 150 \mu \mathrm{m})$ protozoa in a Sedgewick Rafter chamber (S52 glass, Pyser-SGI, Edenbridge, Kent, UK). This was done under an optical microscope with a $10 \times$ objective [21]. In the identification, aliquots of the $10^{-1}$ dilutions were evaluated, together with a drop of lugol, on microscopic slides for visualization of the microstructures of the protozoa, under an optical microscope [27]. The $40 \times$ objective was used to analyze approximately 700 protozoa per animal, which were classified and identified according to the key described in Dehority [26]. All procedures were performed in triplicate.

\section{Statistical analysis}

The daily weight gain (DWG) was calculated from the slope coefficient of the straight line, resulting from the regression of individual body weight measurements, without fasting, as a function of time. This was done using the SAS REG procedure (2004). The performance characteristics and ruminal $\mathrm{pH}$, which showed normal distribution, were analyzed using the Shapiro-Wilk test, by a model that included the effects of sex as a block and IBW as a covariate. The averages were compared by Tukey's test at $5 \%$ probability, using the PROC GLM from SAS (2004).

For the analysis of microbial populations, the concentrations were transformed into $\log _{10}(\mathrm{x}+10)$. The reduction in methylene blue (PRAM); ruminal and fecal values of Enterobacteriaceae, mycelial fungi, and yeasts; and ruminal protozoa that did not show normal distribution, were subjected to the KruskalWallis test at $5 \%$ probability. The frequencies of the bacterial and fungal genera were compared by the Chi-square test $(\mathrm{p}=0.01)$, using PROC NPAR1WAY from SAS (2004).

\section{Results}

Analysis of performance, physicochemical characteristics, and macroscopic characteristics of ruminal fluid

The SC and CC groups did not show significant differences in the DWG, final body weight (FBW), and total weight gain (TWG), as shown in Table-2. 
Table-2: Means and standard deviations (SD) of daily weight gain (DWG), total weight gain (TWG), final body weight (FBW), reduction in methylene blue (PRAM), and hydrogen potential $(\mathrm{pH})$ of Nellore calves supplemented (SC) or not supplemented (CC) with ruminal fungi.

\begin{tabular}{lcccc}
\hline Variables & CC & SC $^{\mathbf{1}}$ & SD & p-value \\
\hline $\begin{array}{l}\text { Performance } \\
\text { DWG (kg/ }\end{array}$ & 0.44 & 0.48 & 0.19 & $0.25^{\mathrm{a}}$ \\
day) & & & & \\
TWG (kg) & 24.00 & 26.63 & 10.82 & $0.26^{\mathrm{a}}$ \\
$\begin{array}{l}\text { FBW (kg) } \\
\text { Ruminal Fluid }\end{array}$ & 294.38 & 275.13 & 38.00 & $0.79^{\mathrm{a}}$ \\
PRAM & 6 min and & 3 min and & 3 min and & $0.14^{\mathrm{b}}$ \\
& $35 \mathrm{~s}$ & $31 \mathrm{~s}$ & $27 \mathrm{~s}$ & \\
pH & 7.43 & 7.15 & 0.29 & $* 0.02^{\mathrm{a}}$ \\
\hline
\end{tabular}

Min=Minutes. Sec $=$ Seconds. ${ }^{\text {TT }}$ Test of comparison of means by the Tukey test with $5 \%$ of significance. ${ }^{\text {bTest }}$ of comparison of means by the Kruskal-Wallis test with $5 \%$ significance. ${ }^{1}$ Supplementation with fungi: Aspergillus terreus (isolated VN15) and Trichoderma longibrachiatum (isolated VN20)

The characteristics of the color, odor, and viscosity of the ruminal fluid were not significantly influenced by fungal inoculation ( $p>0.05)$. The activity of the ruminal microbiota was high, with the PRAM being between 3 and $6 \mathrm{~min}$; however, it too was uninfluenced by supplementation ( $p>0.05-$ Table-2). The ruminal fluid $\mathrm{pH}$ was influenced by supplementation, being lower in SC when compared to CC ( $>>0.05$ - Table-2).

\section{Quantification and identification of Enterobacteriaceae}

The presence of Gram-negative rods that are facultative anaerobes, such as those of the Enterobacteriaceae family, was verified in all samples of ruminal fluid and feces from the evaluated calves. The average concentrations of these bacteria were not influenced by supplementation in SC ( $>0.05$ - Table-3). Similarly, regarding lactose-fermenting Enterobacteriaceae $(\mathrm{Lac}+)$ and non-lactose-fermenting Enterobacteriaceae (Lac-), the mean concentrations were not influenced by supplementation ( $p>0.05$ - Table-3).

Presumptively, 32 colonies of Enterobacteriaceae were identified. Furthermore, it was observed that the sites, ruminal fluid, and feces yielded no significant differences $(p>0.05)$ in the genera of these bacteria, between the groups of calves evaluated (Table-4). From evaluating the frequencies of the genus, Escherichia, the distribution frequency was found to be similar to that of Enterobacter $\mathrm{spp} .(\mathrm{p}=0.01)$, and was more frequent than the Proteus spp. and Providencia spp. (Table-4).

\section{Quantification and identification of facultative anaer- obic fungi}

The average facultative anaerobic fungi in the ruminal fluid $\left(6.2 \times 10^{4} \pm 1.1 \times 10^{5} \mathrm{CFU} / \mathrm{mL}\right)$ and in the feces $\left(2.1 \times 10^{7} \pm 3.9 \times 10^{7} \mathrm{CFU} / \mathrm{g}\right)$ were similar between $\mathrm{SC}$ and $\mathrm{CC}$ groups (Table- 3 ).

The genus of mycelial fungi that were most frequently identified in the samples of ruminal fluid and feces from calves was Aspergillus (Table-5). Nevertheless, it was possible to detect two isolates of
Table-3: Means of colony-forming units (CFU) and standard deviations (SD) of Enterobacteriaceae, mycelial fungi, and yeasts isolated from the ruminal fluid and feces of Nellore calves supplemented (SC) or not supplemented (CC) with ruminal fungi.

\begin{tabular}{lcccc}
\hline Variables & CC & SC $^{1}$ & SD & p-value \\
\hline Ruminal Fluid (CFU/mL) & & & \\
Enterobacteriaceae & $8.9 \times 10^{5}$ & $1.2 \times 10^{5}$ & $1.2 \times 10^{6}$ & 0.20 \\
Lac + & $7.4 \times 10^{5}$ & $8.6 \times 10^{4}$ & $1.0 \times 10^{6}$ & 0.17 \\
Lac - & $1.5 \times 10^{5}$ & $3.2 \times 10^{4}$ & $1.9 \times 10^{5}$ & 0.15 \\
Mycelial Fungi & $1.5 \times 10^{4}$ & $7.6 \times 10^{3}$ & $2.0 \times 10^{4}$ & 0.75 \\
Yeasts & $5.8 \times 10^{4}$ & $5.5 \times 10^{4}$ & $1.1 \times 10^{5}$ & 0.87 \\
Feces (CFU/g) & & & & \\
Enterobacteriaceae & $1.4 \times 10^{6}$ & $9.0 \times 10^{5}$ & $1.7 \times 10^{6}$ & 0.52 \\
Lac + & $1.2 \times 10^{6}$ & $8.8 \times 10^{5}$ & $1.6 \times 10^{6}$ & 0.59 \\
Lac - & $1.7 \times 10^{5}$ & $1.8 \times 10^{4}$ & $2.2 \times 10^{5}$ & 0.28 \\
Mycelial Fungi & $2.6 \times 10^{6}$ & $3.2 \times 10^{5}$ & $4.2 \times 10^{6}$ & 0.99 \\
Yeasts & $1.1 \times 10^{6}$ & $2.1 \times 10^{7}$ & $2.8 \times 10^{7}$ & 0.83 \\
\hline
\end{tabular}

Test of comparison of means by the Kruskal-Wallis test with $5 \%$ significance. Lac+=Lactose fermenting Enterobacteriaceae. Lac-=non-lactose-fermenting Enterobacteriaceae. ${ }^{1}$ Supplementation with fungi: Aspergillus terreus (isolated VN15) and Trichoderma longibrachiatum (isolated VN20)

Table-4: Distribution of Enterobacteriaceae genera isolated from ruminal fluid and feces of Nellore calves supplemented (SC) or not supplemented (CC) with ruminal fungi.

\begin{tabular}{|c|c|c|c|c|c|c|c|c|c|}
\hline \multirow[t]{3}{*}{ Genera } & \multirow{3}{*}{$\begin{array}{c}\text { Total } \\
\text { (n) }\end{array}$} & \multicolumn{4}{|c|}{ Ruminal fluid } & \multicolumn{4}{|c|}{ Feces } \\
\hline & & \multicolumn{2}{|c|}{ CC } & \multicolumn{2}{|c|}{ SC $^{1}$} & \multicolumn{2}{|c|}{ CC } & \multicolumn{2}{|c|}{ SC $^{1}$} \\
\hline & & $\mathbf{n}$ & $\%$ & $\mathbf{n}$ & $\%$ & $\mathbf{n}$ & $\%$ & $\mathbf{n}$ & $\%$ \\
\hline Escherichia spp. & $15^{* *}$ & 1 & 7 & 3 & 20 & 5 & 33 & 6 & \\
\hline Enterobacter spp. & $10 * *$ & 5 & 50 & 3 & 30 & 1 & 10 & 1 & \\
\hline Proteus & 5 & 1 & 20 & 2 & 40 & 1 & 20 & 1 & \\
\hline Providencia spp. & 2 & 1 & 50 & - & - & 1 & 50 & - & \\
\hline Total & 32 & 8 & & 8 & & 8 & & 8 & \\
\hline
\end{tabular}

**Values significantly higher when compared between treatments and between genders using the Chi-square test $(p=0.01) .{ }^{1}$ Supplementation with fungi: Aspergillus terreus (isolated VN15) and Trichoderma longibrachiatum (isolated VN20)

Trichoderma spp. in the ruminal fluid of the SC group and an isolate of Paecilomyces spp. in the feces of an animal from the $\mathrm{CC}$ group (Table-5).

\section{Quantification and identification of genera of rumen protozoa}

The SC group did not differ $(\mathrm{p}>0.05)$ in the total concentration or in the subpopulations of the protozoa (small, medium, and large) in the ruminal fluid, when compared to the CC group (Table-6) [21]. In this study, 11.246 ruminal fluid ciliates were identified and in the analysis of the distribution profile of the Eodinium spp., this genus was detected only in SC $(\mathrm{p}<0.05$ - Table- 6$)$.

\section{Discussion}

Analysis of performance, physicochemical characteristics, and macroscopic characteristics of ruminal fluid

In this study, the supplementation with the two facultative anaerobic fungi in the rumen did 
not significantly change the animals' performance, despite promoting a numerical increase of $2.63 \mathrm{~kg}$ in the average total gain. Different factors, such as the type of microorganism used and its dosage, the nature of the diet, the physiological status of the animal, and the feeding strategy $[28,29]$, could be attributed to the fungi not having an influence on the performance of the calves in the present study. In addition, the animals in this study were still receiving balanced diets and thus, the fungi did not contribute to improving the performance of those calves that received the lignified forage. Despite the low protein value of hay, the total diet met the protein requirements for growing cattle with an average body weight of $280.0 \mathrm{~kg}$ and

Table-5: Distribution of genera of mycelial fungi isolated from the ruminal fluid and feces of Nellore calves supplemented (SC) or not supplemented (CC) with ruminal fungi.

\begin{tabular}{|c|c|c|c|c|c|c|c|c|c|}
\hline \multirow[t]{3}{*}{ Genera } & \multirow{3}{*}{$\begin{array}{c}\text { Total } \\
\text { (n) }\end{array}$} & \multicolumn{4}{|c|}{ Ruminal fluid } & \multicolumn{4}{|c|}{ Feces } \\
\hline & & \multicolumn{2}{|c|}{ CC } & \multicolumn{2}{|c|}{ SC $^{1}$} & \multicolumn{2}{|c|}{$\mathbf{C C}$} & \multicolumn{2}{|c|}{$\mathbf{S C}^{1}$} \\
\hline & & $\mathbf{n}$ & $\%$ & $\mathbf{n}$ & $\%$ & $\mathbf{n}$ & $\%$ & $\mathbf{n}$ & $\%$ \\
\hline Aspergillus spp. & $20 * *$ & 5 & 25 & 5 & 25 & 6 & 30 & 4 & 20 \\
\hline Trichoderma spp. & 2 & - & - & 2 & 100 & - & - & - & - \\
\hline Paecillomyces spp. & 1 & - & - & - & - & 1 & 100 & - & - \\
\hline Total & 23 & 5 & & 7 & & 7 & & 7 & \\
\hline
\end{tabular}

**Values significantly higher when compared between treatments and between genders using the Chi-square test $(p=0.01)$. ${ }^{1}$ Supplementation with fungi: Aspergillus terreus (isolated VN15) and Trichoderma longibrachiatum (isolated VN20) daily weight gain of $0.400 \mathrm{~kg} /$ day, according to the recommendations of the NRC [16]. The low weight gains observed in the present study were compatible with those detected in animals grazing on tropical forages in the dry season of semiarid regions. However, future studies should evaluate diets with increased protein value to favor the improved growth of inoculated fungi and, consequently, their expression of cellulolytic enzymes.

Another study also observed that the DWG $(1.47 \mathrm{~kg} /$ day $)$ was not influenced by the addition of amylase enzymes from Aspergillus awamori in Nellore bulls finished in confinement, who received Tifton hay as bulky hay [30]. However, Aguirre et al. [31] observed that newly weaned Pelibuey sheep, fed with Buffel grass (Cenchrus ciliaris L.), and supplemented with exogenous enzymes from $T$. longibrachiatum, showed improvements in DWG and TWG, in relation to the non-supplemented group.

Supplementation did not alter the patterns of the ruminal fluid's physical characteristics and the PRAM, which were in the normal range according to Dirksen [21]. The $\mathrm{pH}$ considered normal for ruminal fluid is in the range of 5.5-7.6, and is vital for the survival and stability of rumen cellulolytic microorganisms [21]. The $\mathrm{pH}$ of the ruminal fluid in the calves was also within the normal range. However, supplementation reduced $\mathrm{pH}$ values by $3.76 \%$ for $\mathrm{SC}$ when compared to CC. This result could indicate greater levels of microbial activity for animals

Table-6: Mean concentrations, standard deviations (SD), and distribution of protozoan sizes and genera in the ruminal fluid of Nellore calves supplemented (SC) or not supplemented (CC) with ruminal fungi.

\begin{tabular}{|c|c|c|c|c|c|}
\hline \multirow[t]{2}{*}{ Variables } & \multicolumn{2}{|c|}{ CC } & \multicolumn{2}{|c|}{ SC $^{1}$} & \multirow[t]{2}{*}{ p-value } \\
\hline & $\mathrm{n}(/ \mathrm{mL})$ & $\%$ & $\mathrm{n}(/ \mathrm{mL})$ & $\%$ & \\
\hline \multicolumn{6}{|l|}{ Classification by size } \\
\hline Small² & $50.3 \pm 61.8$ & 7.0 & $41.7 \pm 33.2$ & 6.1 & 0.75 \\
\hline Medium $^{2}$ & $624.6 \pm 163.6$ & 87.2 & $582.5 \pm 216.6$ & 84.5 & 0.40 \\
\hline Large $^{2}$ & $41.8 \pm 47.2$ & 5.8 & $64.9 \pm 60.9$ & 9.4 & 0.37 \\
\hline \multicolumn{6}{|l|}{ Genus quantification } \\
\hline Buetschlia spp. & $34.9 \pm 55.1$ & 4.9 & $24.0 \pm 30.3$ & 3.5 & 0.74 \\
\hline Isotricha spp. & $67.5 \pm 53.2$ & 9.4 & $86.5 \pm 35.2$ & 12.6 & 0.26 \\
\hline Dasytricha spp. & $37.0 \pm 39.7$ & 5.2 & $65.7 \pm 48.3$ & 9.5 & 0.26 \\
\hline Charonina spp. & $15.4 \pm 32.2$ & 2.1 & $17.7 \pm 13.1$ & 2.6 & 0.21 \\
\hline Entodinium spp. & $440.5 \pm 136.8$ & 61.3 & $370.6 \pm 203.5$ & 53.8 & 0.24 \\
\hline Diplodinium spp. & $28.6 \pm 29.9$ & 4.0 & $24.6 \pm 12.0$ & 3.0 & 0.91 \\
\hline Eodinium spp. & $0.00 \pm 0.0$ & 0.0 & $6.9 \pm 11.2$ & 1.0 & $* 0.02$ \\
\hline Eremoplaston spp. & $1.1 \pm 2.2$ & 0.2 & $1.6 \pm 4.6$ & 0.2 & 0.64 \\
\hline Eudiplodinium spp. & $14.7 \pm 15.7$ & 2.1 & $24.9 \pm 31.5$ & 3.6 & 0.70 \\
\hline Diploplastron spp. & $27.6 \pm 29.4$ & 3.9 & $16.2 \pm 13.8$ & 2.4 & 0.70 \\
\hline Polyplastron spp. & $13.1 \pm 18.3$ & 1.8 & $4.9 \pm 6.9$ & 0.7 & 0.45 \\
\hline Ostracodinium spp. & $11.6 \pm 16.9$ & 1.6 & $3.7 \pm 5.8$ & 0.5 & 0.58 \\
\hline Elytroplastron spp. & $7.0 \pm 12.6$ & 1.0 & $3.1 \pm 5.9$ & 0.5 & 0.52 \\
\hline Metadinium spp. & $13.5 \pm 16.9$ & 1.9 & $14.5 \pm 11.5$ & 2.1 & 0.55 \\
\hline Enoploplastron spp. & $0.4 \pm 1.1$ & 0.1 & $1.2 \pm 3.5$ & 0.2 & 0.92 \\
\hline Ophyroscolex spp. & $0.4 \pm 1.1$ & 0.1 & $20.6 \pm 44.9$ & 3.0 & 0.19 \\
\hline Epidinium spp. & $4.4 \pm 8.2$ & 0.6 & $3.7 \pm 10.6$ & 0.5 & 0.64 \\
\hline Total & $716.6 \pm 141.4$ & 100.0 & $689.1 \pm 254.3$ & 100.0 & 0.67 \\
\hline
\end{tabular}

Test of comparison of means by the Kruskal-Wallis test with $5 \%$ significance. ${ }^{1}$ Supplementation with fungi: Aspergillus terreus (isolated VN15) and Trichoderma longibrachiatum (isolated VN20). ${ }^{2}$ Small (up to $40 \times 60 \mu$ ) medium (up to $100 \times 150 \mu \mathrm{m})$ and large $(>100 \times 150 \mu \mathrm{m})[21]$ 
that were fed with fibrous diets and evaluated under fasting [21].

In other studies, the addition of fungi and/or fungal enzymes to the ruminant diet improved the microbiota, stabilized rumen $\mathrm{pH}$, promoted microbial degradation of the plant cell wall, and, consequently, helped to improved animal performance $[32,33]$.

\section{Quantification and identification of Enterobacteriaceae genera}

The inclusion of ruminal fungi did not alter the Enterobacteriaceae populations, which presented values close to those of other studies that evaluated calves fed on pasture without supplementation [34]. In another study, after 60 days of experimentation, Stellaa et al. [35] also showed supplementation with a commercial strain of Saccharomyces cerevisiae (CNCM I-1077), in goats of the Saanen breed that were fed with triticale silage $(\times$ Triticosecale Wittmack), did not alter the fecal elimination concentrations of these bacteria when compared to the animals in the control group.

Considering the genus profile of Enterobacteriaceae, Escherichia spp. and Enterobacter spp. were the most identified genera in this study. When evaluating the effect of $S$. cerevisiae supplementation on the diet of crossbred Friesian $\times$ Baladi calves, during the transition period from milk to berseem hay (Trifolium alexandrinum), Hassan et al. [36] reported results similar to the present study with Escherichia spp. being the most identified.

\section{Quantification and identification of the genera of fac- ultative anaerobic fungi}

In this study, the average concentration of facultative mycelial anaerobic fungi and yeasts in the ruminal fluid and in the feces was not significantly influenced by supplementation. However, the detected concentrations were higher than those described by Abrão et al. [9], who detected an average of $3.3 \times 10^{3} \mathrm{CFU} /$ $\mathrm{mL}$ in samples of ruminal fluid from Nellore calves, fed exclusively in tropical pastures of low nutritional value and without supplementation, in northern Minas Gerais, Brazil. This higher concentration could be related to the diet containing the highest grain content for the animals evaluated in the present study.

The genus of mycelial fungi that was most frequently identified in the rumen fluid and in the feces of the calves was Aspergillus. It was also possible to identify two isolates of Trichoderma spp., in ruminal fluid from SC that had morphological characteristics similar to one of the fungi used in the supplementation, indicating that this fungus could remain viable in the rumen environment.

The Aspergillus genus was also the most identified in samples from Nellore calves, fed on pastures of Urochloa spp. without supplementation during the dry season [9]. The predominance of this genus could be justified by its versatility and efficiency in the metabolization of different carbon sources, including lignified cellulose [11,37].
Quantification and identification of genera of rumen protozoa

In this study, supplementation with facultative anaerobic fungi did not influence the average concentration of rumen protozoa. There is a study performed with Nellore calves of both sexes, with the same age group and a feeding regimen similar to the one of this study, but without supplementation with fungi. In that study, Duarte et al. [38] detected a higher population of protozoa $\left(1.7 \pm 9.1 \times 10^{4} / \mathrm{mL}\right)$ in the ruminal fluid. The lower concentration of ciliates observed in the calves evaluated in this study could be justified by the nutritional conditions of the hay used, which had low protein levels and high proportions of lignin, in addition to the fact that the animals remained in isolated stalls, which could have influenced colonization.

In total, 17 genera of protozoa were identified in this study. As described by Wright [39], the genera Entodinium, Isotricha, and Dasytricha were the most frequently found in the evaluated calves. In another study, Duarte et al. [38] detected Buetschilia as the genus of ruminal ciliates most identified in Nellore calves that were raised in tropical pastures during the dry season, without supplementation. The diversity of the genera of these eukaryotes may indicate a healthy ruminal environment [40], as even in the dry season, it was possible to observe this in our study.

Among the protozoa identified, Eodinium spp. was detected only in SC. This genus of protozoa is a member of the Ophryoscolecidae family, which is preferably characterized as cellulolytic [41] and considered important for the degradation of cellulose present in the forage used. Silva et al. [40] and Nigri et al. [42] also included the genus Eodinium among those most frequently found in Nellore steers fed with Urochloa spp. hay, without supplementation.

\section{Conclusion}

The supplementation with the two selected isolates of A. terreus and T. longibrachiatum has potential for use as possible additives. This is because they did not alter the physiological parameters of the composition of the facultative anaerobic microbiota of the rumen and feces. Furthermore, they also favor the presence of the protozoa, Eodinium spp. However, future studies should be performed to better define the dosages and strategies for use in supplementing the diet of calves.

\section{Authors' Contributions}

ASC and ERD: Designed the study and drafted and revised the manuscript. LMGF, PPXC, and VSMJ: Managed the animals. SAF: Participated in assembling the microorganism strains and culture conditions. TAXS: Participated in the assembling of the microorganism strains and culture conditions and wrote and revised the paper. All authors have read and approved the final manuscript. 


\section{Acknowledgments}

The research was funded by the Research Support Foundation of Minas Gerais (FAPEMIG) (ppm 00393-17), the National Council for Scientific and Technological Development (CNPq) (projects 310898/2018-8 and 433089/2016-4), Pró -Dean of Research at the Federal University of Minas Gerais (PRPq-UFMG), Coordination for the Improvement of Higher Education Personnel - Brazil (CAPES) - Financial Code 001 and Connan - Animal Nutrition.

\section{Competing Interests} interests.

The authors declare that they have no competing

\section{Publisher's Note}

Veterinary World remains neutral with regard to jurisdictional claims in published institutional affiliation.

\section{References}

1. Malmuthuge, N., Chen, Y., Liang, G., Goonewardene, L.A. and Guan, L.L. (2015) Heat-treated colostrum feeding promotes beneficial bacteria colonization in the small intestine of neonatal calves. J. Dairy Sci., 98(11): 8044-8053.

2. Zhang, L., Boeren, S., Hageman, J.A., van Hooijdonk, T., Vervoort, J. and Hettinga, K. (2015) Bovine milk proteome in the first 9 days: Protein interactions in maturation of the immune and digestive system of the newborn. PLoS One, 10(2): $\mathrm{e} 0116710$.

3. Hammon, H.M., Liermann, W., Frieten, D. and Koch, C. (2020) Review: Importance of colostrum supply and milk feeding intensity on gastrointestinal and systemic development in calves. Animal, 14(S1): 133-143.

4. Timmerman, H.M., Mulder, L., Everts, H., van Espen, D.C., van der Wal, E., Klaassen, G., Rouwers, S.M., Hartemink, R., Rombouts, F.M. and Beynen, A.C. (2005) Health and growth of veal calves fed milk replacers with or without probiotics. J. Dairy Sci., 88(6): 2154-2165.

5. Paul, K., Nonoh, J.O., Mikulski, L. and Brune, A. (2012) "Methanoplasmatales", thermoplasmatales-related Archaea in termite guts and other environments, are the seventh order of methanogens. Appl. Environ. Microbiol., 78(23): $8245-8253$.

6. Gruninger, R.J., Puniya, A.K., Callaghan, T.M., Edwards, J.E., Youssef, N., Dagar, S.S., Fliegerova, K., Griffith G.W., Forster, R., Tsang, A., McAllister, T. and Elshahed, M.S. (2014) Anaerobic fungi (phylum Neocallimastigomycota): Advances in understanding their taxonomy, life cycle, ecology, role and biotechnological potential. FEMS Microbiol. Ecol., 90(1): 1-17.

7. Stivari, T.S.S., Chen, R.F.F., Gameiro,A.H., Monteiro,A.L.G., Raineri, C. and Silva, J.B.A. (2014) Feasibility of grazing sheep production systems using long-term economic indicators and the methodology of the soil expectation value. Braz. J. Vet. Res. Anim. Sci., 51(2): 149-157.

8. Freitas, C.E.S., Abrão, F.O., Silva, K.L., Almeida, P.N.M and Duarte, E.R. (2012) Aerobic fungi in the large intestine of lambs and ewes raised on tropical pastures Arq. Bras. Med. Zootec., 64(1): 225-227.

9. Abrão, F.O., Duarte, E.R., Freitas, C.E., Vieira, E.A., Gerassev, L.C., Silva-Hughes, A.F., Rosa, C.A. and Rodrigues, N.M. (2014) Characterization of fungi from ruminal fluid of beef cattle with different ages and raised in tropical lignified pastures. Curr. Microbiol., 69(2): 649-659.

10. Almeida, P.N.M., Freitas, C.E., Abrão, F.O., Ribeiro,
I.C.O., Vieira, E.A., Geraseev, L.C. and Duarte, E.R. (2014) Atividade celulolítica de fungos aerobios isolados do rúmen de bovinos leiteiros alimentados com forragens tropicais. Rev. Caatinga, 27(4): 202-207.

11. Abrão, F.O., Duarte, E.R., Pessoa, M.S., Santos, V.L., Freitas Júnior, L.F., Barros, K.O., Silva-Hughes, A.F., Silva, T.D. and Rodriguez, N.M. (2017) Notable fibrolytic enzyme production by Aspergillus spp. isolates from the gastrointestinal tract of beef cattle fed in lignified pastures. PLoS One, 12(8): 1-13.

12. Facchini, F.D.A., Vici, A.C., Reis, V.R.A., Jorge, J.A., Terenzi, H.F., Reis, R.A. and Polizeli, M.L. (2011) Production of fibrolytic enzymes by Aspergillus japonicus C03 using agro-industrial residues with potential application as additives in animal feed. Bioprocess Biosyst. Eng., 34(3): 347-355.

13. Gomes, J.E.G., Nascimento, T.C.E., Queiroz, A.E.S., de Siqueira Silva, J.I. Jr., Souza-Motta, C.M., Medeiros, E.V. and Moreira, K.A. (2014) Characterization and evaluation of in vitro digestion of phytases, xylanases and cellulases for feed industry. Afr. J. Microbiol. Res., 8(6): 551-558.

14. Abrão, F.O., Duarte, E.R., Pessoa, M.S., Santos, V.L. and Rodriguez, N.M. (2018) Mycotoxicological safety and viability of Aspergillus spp. with probiotic potential from the bovine digestive tract. Arq. Bras. Med. Zootec., 70(6): 1833-1839.

15. INMET-Instituto Nacional de Meteorologia. (2020) Portuguese. Available from: http://www.inmet.gov. $\mathrm{br} / \mathrm{projetos} / \mathrm{rede} / \mathrm{pesquisa/gera}$ _serie_txt_mensal. php? \& mrelestacao $=83437 \&$ btnprocesso $=$ serie $\&$ mreldtinicio $=01 / 04 / 2020 \&$ mreldtfim $=01 / 10 / 2020 \&$ matributos $=.1 .1 .1$ Retrieved on 02-04-2020.

16. NRC-National Research Council. (2016) Nutrient Requirements of Beef Cattle. $8^{\text {th }}$ ed. Eighth Revised Edition, Washington, DC. p494.

17. AOAC-Association of Official Analytical Chemists. (1975) Official Methods of Analysis. 12 $2^{\text {th }}$ ed. Association of Analytical Chemistry, Washington. DC. p1094.

18. Van Soest, P.J., Robertson, J.B. and Lewis, B.A. (1991) Symposium: Carbohydrate methodology, metabolism and nutritional implications in dairy cattle methods for dietary fiber, neutral detergent fiber and nonstarch polysaccharides in relation to animal nutrition. J. Dairy Sci., 74(10): 3583-3597.

19. Altschul, S.F., Madden, T.L., Schaffer, A.A., Zhang, J.Z.Z., Miller, W. and Lipman, D.J. (1997) Gapped BLAST and PSI-BLAST: A new generation of protein database search programs. Nucleic Acids Res., 25(17): 3389-3402.

20. Freitas, C.E.S. (2018) Fungos do Trato Digestório de Ruminantes Como Potencial Probiótico Para Ovinos, Tese. Universidade Estadual do Sudoeste da Bahia, Brasil. p83.

21. Dirksen, G. (1993) Sistema digestivo In: Dirksen, G., Grunder, H.D., Stober, M. and Rosenberger, M., editors. Exame Clínico dos Bovinos. $3^{\text {rd }}$ ed. Guanabara Koogan, Rio de Janeiro. p167-169.

22. Murray, P.R., Baron, E.J., Jorgensen, J.H., Landry, M.L. and Pfaller, M.A. (2007) Manual of Clínical Microbiology. $9^{\text {th }}$ ed. American Society for Microbiology, Washington, DC. p2488.

23. McFaddin, J.F. (2000) Biochemical Tests for Identification of Medical Bacteria. $3^{\text {rd }}$ ed. Lippincott Williams and Wilkins, Philadelphia, PA. p912.

24. Lacaz, C.S., Porto, E., Martins, J.E.C., Heins-Vaccari, E.M. and Takahashi, N.M. (2002) Tratado de Micologia Médica. $9^{\text {th }}$ ed. Sarvier, São Paulo. p1104.

25. Germain, G.S. and Summerbell, R. (2010) Identifying Fungi: A Clinical Laboratory Handbook. $2^{\text {nd }}$ ed. Star Publishing Company, Belmont, CA. p377.

26. Dehority, B.A. (1993) Laboratory Manual for Classification and Morphology of Rumen Ciliate Protozoa. CRC Press Inc., Florida. p96.

27. D'Agosto, M. and Carneiro, M.E. (1999) Evaluation of lugol solution used for counting rumen ciliates. Rev. Bras. Zool., 16(1): 725-729. 
28. Chaucheyras-Durand, F., Walker, N.D. and Bach, A. (2008) Effects of active dry yeasts on the rumen microbial ecosystem: Past, present and future. Anim. Feed Sci. Technol., 145(1-4): 5-26.

29. Alugongo, G.M., Xiao, J., Wu, Z., Li, S., Wang, Y. and Cao, Z. (2017) Review: Utilization of yeast of Saccharomyces cerevisiae origin in artificially raised calves. J. Anim. Sci. Biotechnol., 8(34): 1-12.

30. Oliveira, L.G., Ferreira, R.N., Padua, J.T., Ulhoa, C.J., Cysneiros, C.S.S. and Arnhold, E. (2015) Performance of beef cattle bulls in feedlots and fed on diets containing enzymatic complex. Acta Sci. Technol., 37(2): 181-186.

31. Aguirre, D.L., Hernández-Meléndez, J., Rojo, R., SánchezDávila, F., López-Villalobos, N., Salem, A.Z.M., MartínezGonzález, J.C., Vázquez-Armijo, J.F. and Ruíz, S. (2016) Effects of exogenous enzymes and application method on nutrient intake, digestibility and growth performance of Pelibuey lambs. Springerplus, 5(1): 1399.

32. Tripathi, V.K., Sehgal, J.P., Puniya, A.K. and Singh, K. (2007) Effect of administration of anaerobic fungi isolated from cattle and wild blue bull (Boselaphus tragocamelus) on growth rate and fibre utilization in buffalo calves. Arch. Anim. Nutr., 61(5): 416-423.

33. Alzahal, O., Dionissopoulos, L., Laarman, A.H., Walker, N. and McBride, B.W. (2014) Active dry Saccharomyces cerevisiae can alleviate the effect of subacute ruminal acidosis in lactating dairy cows. J. Dairy Sci., 97(12): 7751-7763.

34. Vieira, E.A., Abrão, F.O., Ribeiro, I.C.O., Nigri, A.C.A., Silva, K.F., Careli, R.T., Geraseev, L.C. and Duarte, E.R. (2015) Aerobes and anaerobe facultative Gram-negative rod-shaped bacteria in the ruminal fluid of beef cattle fed lignified pasture and steers with ruminal acidosis Pesqui. Vet. Bras., 35(9): 811-816.

35. Stellaa, A.V., Parattea, R., Valnegria, L., Cigalinoa, G., Soncinia, G., Chevaux, E., Dell'Ortoa, V. and Savoni, G. (2007) Effect of administration of live Saccharomyces cerevisiae on milk production, milk composition, blood metabolites, and faecal flora in early lactating dairy goats. Small Rumin. Res., 67(1): 7-13.

36. Hassan, A.A., Salem, A.Z.M., Kholif, A.E., Samir, M., Yacout, M.H., Abu Hafsa, S.H., Mendoza, G.D., Elghandour, M.M.Y., Ayala, M. and Lopez, S. (2016) Performance of crossbred dairy Friesian calves fed two levels of Saccharomyces cerevisiae: Intake, digestion, ruminal fermentation, blood parameters and faecal pathogenic bacteria. J. Agric. Sci., 154(8): 1488-1498.

37. Flipphi, M., Sun, J., Robellet, X., Karaffa, L., Fekete, E., Zeng, A.P. and Kubicek, C.P. (2009) Biodiversity and evoulution of primary carbon metabolism in Aspergillus nidulans and other Aspergillus spp. Fungal Genet. Biol., 46(1): 19-44.

38. Duarte, E.R., Abrão, F.O., Ribeiro, I.C.O., Vieira, E.A., Nigri, A.C., Silva, L.K., Virgínio-Júnior, G.F., Barreto, S.M.P. and Gerassev, L.C. (2018) Rumen protozoa of different ages of beef cattle raised in tropical pastures during the dry season. J. Appl. Anim. Res., 46(1): 1457-1461.

39. Wright, A.D.G. (2015) Rumen protozoa. In: Puniya, A.K., Singh, R. and Kamra, D.N., editors. Rumen Microbiology: From Evolution to Revolution. Springer, India. p379.

40. Silva, K.L., Duarte, E.R., Freitas, C.E.S., Abrão, F.O. and Geraseev, L.C. (2014) Rumen protozoa of steers raised on tropical pasture during dry season. Ciênc. Anim. Bras., 15(3): 259-265.

41. Coppo, J.A., Mussart, N.B., Revidatti, M.A. and Capellari, A. (2003) Absence of biochemically demonstrable stress in early weaned half-bred zebu calves. Agric. Nat. Resour., 30(2): 97-105.

42. Nigri, A.C.A., Ribeiro, I.C.O., Vieira, E.A., Silva, M.L.F., Virgínio-Júnior, G.F., Abrão, F.O., Geraseev, L.C. and Duarte, E.R. (2017) Population of protozoa in zebu steers fed with or without bulk. Arq. Bras. Med. Zootec., 69(5): 1339-1345.

$* * * * * * * *$ 